\title{
Identification of Fossil Wood from Samarinda, East Borneo
}

\author{
Nani Husien ${ }^{1, *}$ Sri Wahyuni ${ }^{1}$ Erwin ${ }^{1}$ Agus Sulistyo Budi ${ }^{1}$ \\ ${ }^{1}$ Laboratory of Wood Biology. Forestry Faculty Mulawarman University, Samarinda \\ *Corresponding author.Email: nani_husien@yahoo.com
}

\begin{abstract}
This study aims to identify the anatomical structure of petrified wood discovered in Samarinda, East Borneo. The material consists of a single piece of petrified wood, grey, and white - the ground thin-section technique prepared three-dimensional sections (transverse, tangential, and radial). Microscopic characters of the fossil wood were compared with the present wood species. The existence of wood pores characterizes specimens microscopically identified as the petrified wood of hardwood. Further, the xylotomical characters were comparable with the family Dipterocarpaceae. The fossil wood shows a close resemblance with the genus of Shoreaxylon in respect of size and arrangement of pores, rays, and axial parenchyma. The similarity was found on two preparates of Shorea's anatomical properties, which are used as comparisons. Therefore, based on these properties, the species of this petrified wood is undoubtedly the genus of Shoreoxylon.
\end{abstract}

Keywords: Morphological, Anatomical, Fossil wood

\section{INTRODUCTION}

In Indonesia, petrified wood is found almost everywhere, in districts and cities or forest areas, as reported and published by [1-6]. Fossil wood in this research is a single log of petrified wood with 1-meter length, discovered in Mugirejo village, Samarinda, about $5 \mathrm{~km}$ away from the city center. The log's position was in the foothills (Figure 1). A land digger found the fossil in the elevation of $29 \mathrm{~m}$. A fossil in Indonesia came from the Miocene to Pliocene, 25 million years BP (Before Present) to 2 million years BP. The local geologist estimated that this fossil wood-aged less than 2 million years [2,3]. This is based on the analysis of soil formation around the fossils found.

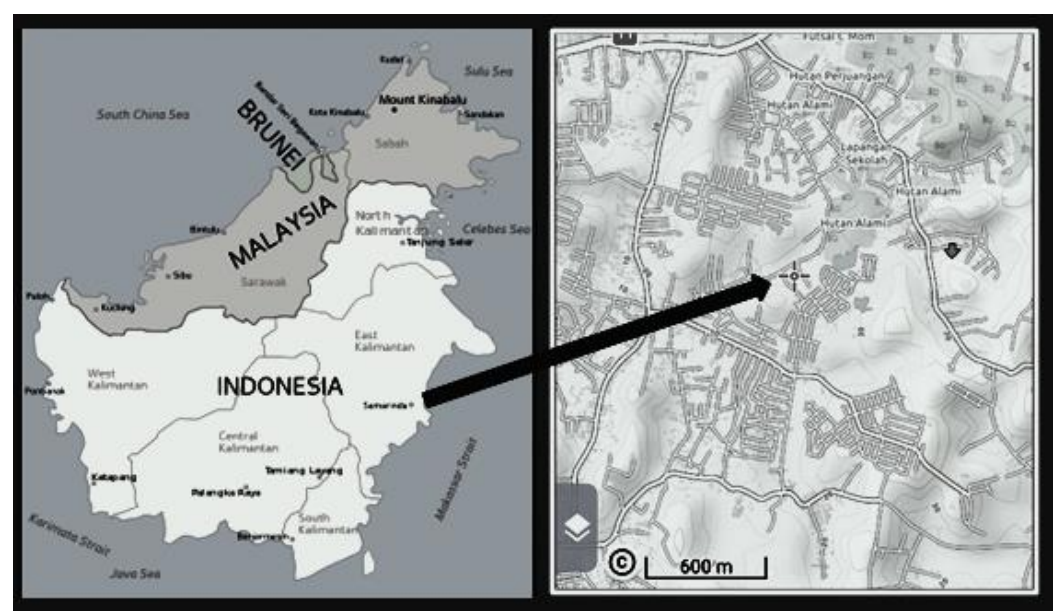

Figure 1 Fossil Site in Mugirejo Village, Samarinda, East Borneo 


\section{MATERIAL AND METHOD}

The fossil wood specimen was from Mugirejo village, Samarinda, East Borneo. The specimen was cut in the dimension of $6 \times 5 \times 5 \mathrm{~cm}$. And it has a grey and white color. Transverse, tangential, and radial sections were prepared by ground thin-section technique at the laboratory of geological Museum, Bandung, West Java, with the procedure as follows: 1) The petrified wood was cut into three sections, transverse, tangential, and radial and cleaned with water to remove dust and mud. The petrified wood was then polished using hand sanders with different coarseness, beginning with the most coarse), increasing to a medium, and its anatomical structure at the same time was observed by microscope. 2) Each piece of each petrified wood section took approximately 10-15 minutes to polish until the specimens' anatomical structure was seen clearly.

Photographs for macroscopical analysis were taken by Microscopic camera (Canon Coolpix D8400), of all three sections and analyzed with light microscope Eclipse E400, and for detail anatomical structure were examined by light microscope (Olympus $\mathrm{BH} 2$ ), in the laboratory of wood biology, Forestry Faculty, University of Mulawarman, Samarinda, East Borneo. The petrified wood pattern was then compared to some preparates pictures of present wood, picture of wood in the reference materials [7] and compare with two preparates of the Genus Shorea and analyzed further using xylarium's wood identification method, Bogor.

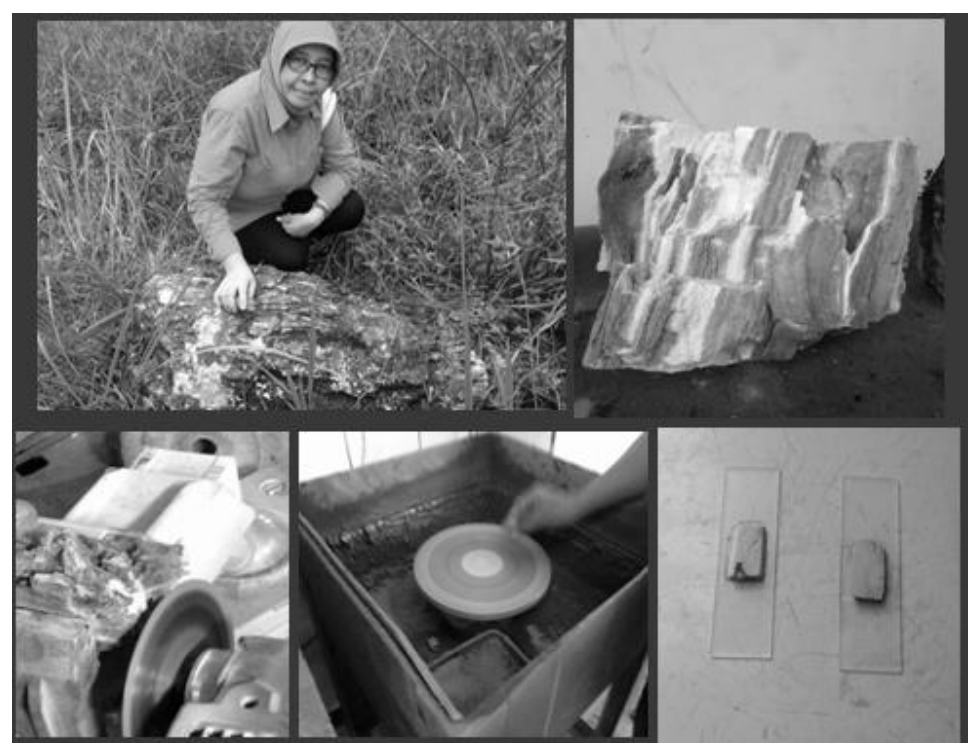

Figure 2 A Piece of Petrified Wood and Research Equipments

\section{RESULT AND DISCUSSION}

\subsection{Morphological Description}

One piece of wood fossil is with a dimension $6 \times 5 \times 5 \mathrm{~cm}$. The color of fossilized wood is grey and striped black and white on the surface, and the hardness was 3-3,5Mohs. The wood fiber's line can still be seen clearly, and the specimens are easy to cut (Figure 2). Almost all transverse surface pores were filled with a white and yellow substance (Fig.3) but not seen in both the tangential and radial sections.

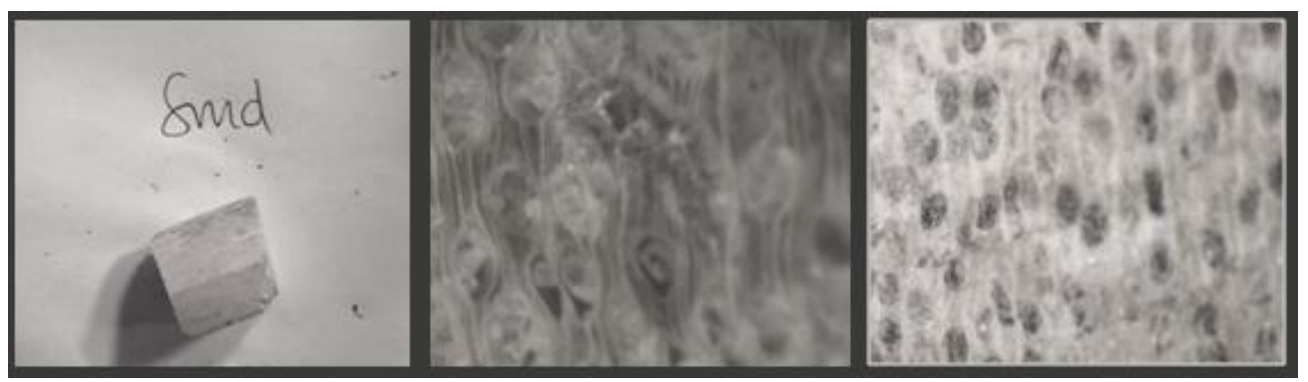

Figure 3 Macroscopical feature: small specimen and pores filled with substance 


\subsection{Anatomical Description}

\subsubsection{Transverse section}

The specimen is a porous wood with growth ring boundaries indistinct or absent. Vessels round and oval, diffuse-porous arrangement, some in diagonal and radial pattern, tangential diameter varies from 149-250 $\mu \mathrm{m}$; solitary vessels (more) and double vessels (fewer), amount of pores 6-10 per square $\mathrm{mm}$ ); some pores filled with a yellow substance (Figure 3). In the type of present Dipterocarp, this yellow substance is known as gum. Perforation and axial parenchyma on this surface area are indistinct - broad rays and straight to the radial direction. As seen in figure (4), the arrangement of the intercellular axial canal was spread unevenly. This structure is commonly found in the Hardwood group belonging to the family of Dipterocarpaceae. Still, the certainty that the fossil wood was seen as a Dipterocarpaceae species could not be ascertained because this research is still in progress.

\subsubsection{Tangential section}

Vessels in tangential are unlike in the transverse surface unfilled (empty of material). It has simple perforation. The length of vessel elements is $257 \mu \mathrm{m}$ $470 \mu \mathrm{m}$. Rays are long and moderate with multiseriate type, mostly 3-5 cells: rays width $25 \mu \mathrm{m}$ and $230 \mu \mathrm{m}$ in high. Amount of rays are 6-10 cell per mm. Xylem rays are heterogeneous due to the different sizes inside the cell rays, and they can be seen clearly.

\subsubsection{Tangential section}

In the tangential section, vessels in the radial section are also not filled with any substance. Vessels segments are elongated, having truncated ends. The vessel's length ranges from 222-361 $\mu \mathrm{m}$ and 131-266 $\mu \mathrm{m}$ in width, the vessel with simple perforation. Axial parenchyma cells are diffuse-heterogeneous rays parenchyma, with several rows of upright and square marginal cells.

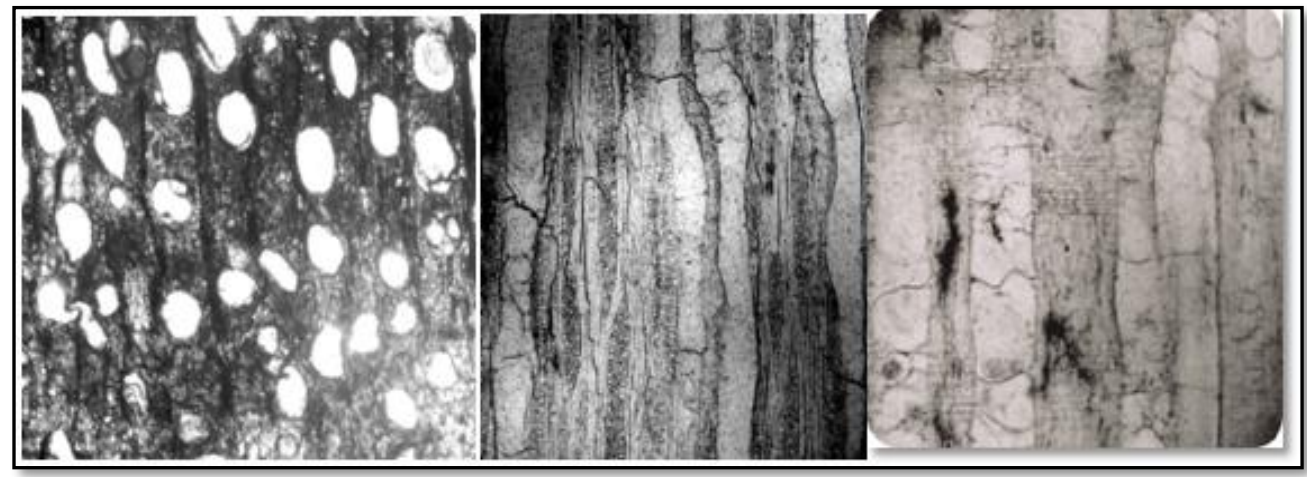

Figure 4 Microscopical Feature, Tranverse, Tangential and Radial Section of Wood Fossil
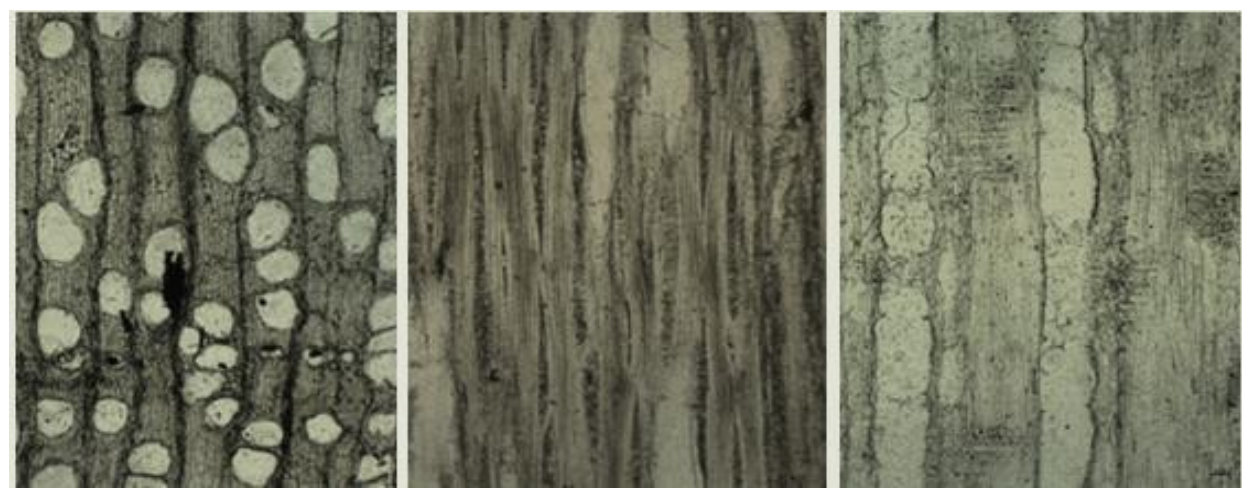

Figure 5 Microscopical Feature of Shoreoxylon from [2]

\subsection{Comparison with Present Wood}

The most important anatomical features exhibited by the fossil wood are wood diffuse-porous vessels, mostly solitary or double 2-3, but rare; Axial parenchyma diffuse: rays moderate, 3-5 seriate heterogeneously. Considering the above-mentioned xylotomical characters show its affinity with the wood of
Shoreoxylon, family Dipterocarpaceae. But further can be distinguished by the arrangement of the radial pores which have placed the fossil wood under investigation nearer to the family Myrtaceae. The fossil under investigation shows similarities in most anatomical detail with the genus Shoreoxylon, family Dipterocarpaceae. 
Table 1. Comparison of Wood Fossil related to Genus Sorea

\begin{tabular}{|c|c|c|c|c|}
\hline Species & Porous Wood & Vessel & Parenchyma & Rays \\
\hline Shorealeprosula & diffuse-porous & $\begin{array}{l}\text { Medium size } \\
\text { diameter } 155-350 \\
\mu \mathrm{m}, \text { most solitary, } \\
\text { rare in multiples, } \\
\text { commonly short } \\
\text { (2-3 vessels). The } \\
\text { average number of } \\
\text { vessels/mm² } 4-8 \text {. } \\
\text { Simple } \\
\text { Perforation. }\end{array}$ & $\begin{array}{l}\text { Axial parenchyma } \\
\text { rarely apotracheal, or } \\
\text { paratracheal. } \\
\text { Apotracheal axial } \\
\text { parenchyma diffuse. }\end{array}$ & $\begin{array}{l}\text { Rays } 4-8 \text { per } \\
\text { tangential mm, } \\
\text { multiseriate, } 2-6 \text { cells } \\
\text { wide. Height of large } \\
\text { rays commonly } 500 \\
\text { to } 1000 \mu \mathrm{m} \text {, or over } \\
1000 \mu \mathrm{m} \text {. Rays are } \\
\text { composed of two or } \\
\text { more cell types, } \\
\text { heterocellular. }\end{array}$ \\
\hline Shoreaovata & diffuse-porous. & $\begin{array}{l}\text { Vessels in } \\
\text { multiples, } \\
\text { commonly short } \\
\text { (2-3 vessels) in } \\
\text { radial rows. } \\
\text { Average tangential } \\
\text { diameter 150-295 } \\
\mu \mathrm{m} \text {. Average } \\
\text { number/mm² 3-9. } \\
\text { Simple } \\
\text { Perforation. pits } \\
\text { alternate, with } \\
\text { distinct borders or } \\
\text { with reduced } \\
\text { borders. }\end{array}$ & $\begin{array}{l}\text { Rarely, banded (axial } \\
\text { resin canals embedded } \\
\text { in parenchyma bands). } \\
\text { apotracheal, or } \\
\text { paratracheal. } \\
\text { Apotracheal diffuse } \\
\text { and diffuse-in- } \\
\text { aggregates. } \\
\text { Paratrachealvasicentric, } \\
\text { aliform, and unilateral. } \\
\text { Average number of } \\
\text { cells per axial } \\
\text { parenchyma strand } 4 .\end{array}$ & $\begin{array}{l}\text { Multiseriate, } 4-8 \text { per } \\
\text { tangential mm, } 2-6 \\
\text { cells wide. Height of } \\
\text { large rays commonly } \\
500 \text { to } 1000 \mu \mathrm{m} \text {, or } \\
\text { over } 1000 \mu \mathrm{m} \text {. } \\
\text { Heterocellular rays } \\
\text { with square and } \\
\text { upright cells } \\
\text { restricted to marginal } \\
\text { rows, mostly } 1 \\
\text { marginal row of } \\
\text { upright or square } \\
\text { cells or mostly } 2-4 \\
\text { marginal rows of } \\
\text { upright }\end{array}$ \\
\hline Fossil wood & $\begin{array}{l}\text { Diffuse } \\
\text { porous }\end{array}$ & $\begin{array}{l}\text { Medium size, } \\
149-266 \mu \mathrm{m} \text { in } \\
\text { diameter, few } \\
6-10 \text { vessels / } \\
\text { sq.mm, mostly } \\
\text { solitary and rare } \\
\text { double, simple } \\
\text { perforation }\end{array}$ & $\begin{array}{l}\text { Axial parenchyma } \\
\text { rarely apotracheal, or } \\
\text { paratracheal. } \\
\text { Apotracheal axial } \\
\text { parenchyma diffuse. }\end{array}$ & $\begin{array}{l}\text { Multiseriate rays, } \\
\text { medium } 2-5 \text { seriate, } \\
2-10 \\
\text { cells high, } 6-10 \\
\text { rays } / \mathrm{mm} 2 .\end{array}$ \\
\hline
\end{tabular}

To identify more details of this wood fossil's genus, the identification method of Bogor's xylarium was used. The result showed that the characteristics found on the wood fossil preparate are characteristics number: $02,05,10,13,42,58,69,76,97,106,107,115,127$ where these characters belong to the genus of Shoreoxylon.

\section{CONCLUSION}

The wood fossils found in Samarinda belong to the hardwood class (broadleaf) and more resembles the genus Shoreoxylon, the family of Dipterocarpaceae, characterized by the diffuse pores (vessels) arrangement, which was seen on the transverse section, as well as their multiseriate rays line. Paratracheal and apotracheal rare axial parenchyma arrangement, multiseriate heterogeneous rays type, and diffuse interseluler axial (axial canal) are typical features Shorea, is found in the transversal section in this wood fossil specimen.

\section{ACKNOWLEDGMENTS}

We thank Mr.Idrus and Mr.Fendi, who have allowed and shared some fossil samples from their work area to be analyzed; for this, we are immensely grateful and to Mr.Yadi for assistance and helping in the workshop during research.

\section{REFERENCES}

[1] K. Noriko, I.M. Yance, T. Kazuo, K. Yamada, H. Sapri, A case study of silisified Fossil wood in Java island, Indonesia, 2002.

[2] Andianto, E.L. Neo, I. Agus, Identification of wood fossils from Cemoro river, Sragen Regency, central Java, in Proceeding of biology seminar, Biology Faculty University of Gajah Mada. Yogyakarta, 2010. 
[3] M.D. Listya, I.M. Yance, R. Sri, Suprihatna, A new record of shoreoxylon (Dipterocarpaceae), Fossil wood from Flores island Indonesia, 2012.

[4] I. Yance, K. Noriko, A fossil wood of Dipterocarpaceae from Pliocene deposit in the west region of java island, Indonesia, Journal of Biodiversitas 5(1) (2004) 28-35.

[5] M.D. Listya, research on wood fossils, its status and prospects in Indonesia, 2013.

[6] H. Nani, S.B. Agus, Gandi, Preliminary research: Feature of cross-section, hardness, and specific gravity some petrified woods from Loa Janan, Kutai Kertanegara, East Kalimantan, Journal Modern Environmental Science and Engineering 10 (2016) 716-722.

[7] IAWA Committee, IAWA List of microscopic features for hardwood identification rijksherbarium, IAWA Bull. n.s. 10 (1989) 219332. 